\title{
表層浸透能の変化を考慮した 多摩丘陵都市流域における水循環解析 ANALYSIS OF HYDROLOGCAL CYCLE IN AN URBAN BASIN IN THE TAMA HILLS CONSIDEREING INFILTRATION VARIATION IN UPPER SOIL LAYER
}

\author{
藤村和正 1 - 安藤義久 2 \\ Kazumasa FUJIMURA and Yosihisa ANDO \\ 1正会員 博 (工) 明星大学講師 理工学部土木工学科（†191-8506 東京都日野市程久保2-1-1) \\ 2フェロー 工博 東京都立大学大学院教授 工学研究科（テ192-0397 東京都八王子市南大沢1-1)
}

\begin{abstract}
Infiltration models are used to estimate the effective rainfall for runoff analysis, and its role is important for the accurate simulation of a runoff hydrograph. Only a few infiltration models take rainfall intensities into account. The infiltration model proposed recently by Diskin and Nazimov (1995) takes into consideration the rainfall intensity variations, and it can also be used to calculate the variation of the infiltration capacity for unsteady rainfall. This infiltration model is a fairly simple conceptual model. In this paper, the Diskin-Nazimov infiltration model is applied to the actual runoff analysis, and validates the runoff model's applicability. Concretely, the lumped hourly hydrological model presented by Ando et al. (1981) is coupled with the Diskin-Nazimov infiltration model to calculate the effective rainfall. The study basin is the Kotta River basin which is located in Tama New Town, an urban development in the Tama hills, in the western suburbs of Tokyo. The results showed that the calculated hydrographs represent the observed hydrographs for long-term rainfall runoff events in the Kotta River basin.
\end{abstract}

Key Words : Rainfall infiltration model, rainfall intensity variation, infiltration variation, lumped hydrological model, urban basin

\section{1.はじめに}

流出解析を行う場合、有効降雨を正確に算定すること は、解析精度を向上させる上で重要である。降雨を流出 成分と浸透成分に分けることは雨水浸透モデルによって 行われるが、降雨強度を考虑して浸透能計算を行う雨水 浸透モデルは数少ない。実際の浸透現象は、降雨強度が 大きくなれば土㙵の水分量は増加し、それに従い浸透能 は小さくなり、逆に、降雨強度が小さくなれば、あるい は無降雨時間が続けば土壌の水分量は減少し、浸透能は 大きくなる。このように浸透能の変化は明らかに降雨強 度と密接に関係していると言える。1970年代、Smith ${ }^{1)}$ PMein and Larson ${ }^{2)}$ は降雨強度を考慮した浸透能式の 開発を行った。1995年、Diskin and Nazimov ${ }^{3}$ は、降雨 強度を考慮できる比較的簡単な構造の雨水浸透モデル

（以下、Diskin-Nazimovモデルと呼ぶ）を提案した。彼 らは、文献上の資料を用いて浸透能解析を行いモデルの 妥当性を示している。藤村 ・安藤・山田・山中 ${ }^{4}$ および Fujimura and $\left.A \mathrm{Ando}^{5}\right)$ は散水浸透実験を行い、現地におけ
るDiskin-Nazimovモデルの妥当性を示した。

本研究では、Diskin-Nazimovモデルが比較的䉍単な構 造でありながら降雨強度の変化を考慮した浸透能計算が でき、そして、現地浸透実験によりその妥当性が示され たことから、本モデルを流出解析に適用することを行う。 具体的には、安藤・虫明・高橋 $\left.{ }^{6}\right)$ が開発した集中型の 1 時間単位計算の水循環モデルに有効降雨モデルとして Diskin-Nazimovモデルを組み込み、多摩ニュータウン地 域の都市河川流域である乞田川流域において1996年3月 末から 2001 年 2 月にわたる約 5 年間を対象期間として水循 環解析を行い、その適合性について検討することを目的 とする。なお、本研究では、Diskin-Nazimovモデルにつ いて、その構造と降雨強度の変化を考慮した浸透能計算 の方法についても概要を説明する。

\section{2. 対象流域の概要}

\section{（1）乞田川流域の概要}

本研究の対象流域は、多摩ニュータウン地区の乞田川 流域であり、流域面積は $14.1 \mathrm{~km}^{2}$ である。流域の形状は、 図ー 1 に示すように、南側の斜面が長く、何本もの支川 


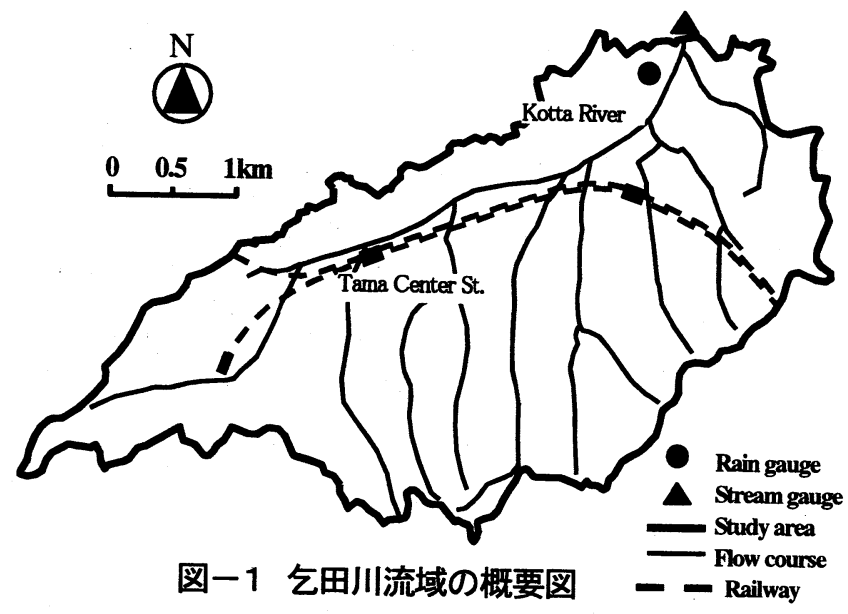

表-1 土地利用別面積率と終期浸透能

\begin{tabular}{|c|c|c|c|c|c|c|}
\hline & 道路 & 屋根 & 芝地 & グランド & 造成地 & 林地 \\
\hline 面積率(\%) & 35.4 & 21.2 & 22.5 & 5.2 & 6.7 & 9.0 \\
\hline
\end{tabular}

が発達しているが、北側の斜面は短い。乞田川本川は、 流域末端の水位観測地点から数百メートル下流で同じ丘 陵地河川の大栗川と合流し、さらにその約 $1.5 \mathrm{~km}$ 下流で 多摩川と合流している。流域は多摩丘陵に位置しており、 地質構造は、表層部には関東ロームが数メートルから数 十メートルの厚さで堆積しており、その下には層厚5m前

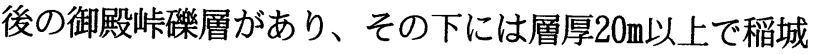
砂層があり、その下に連光寺互層がある。この連光寺互 層が流域の帯水層の不透水性基盤となり地下水流出が発 生していると考えられている7)。

本流域一帯は1.965年頃より多摩ニュータウン事業とし て大規模な都市開発が進められた。現在では開発はほぼ 完了している。表一 1 上段には土地利用別の面積率を示 す。これは1/2500の地形図から交点法により読取った值 であり、不浸透域は道路の $35.4 \%$ と屋根の $21.2 \%$ 合計で

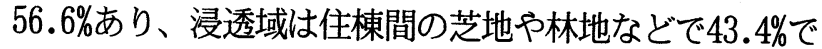
ある。このことから本流域は完全な都市流域であること が分かる。流域には分流式の下水道が整備され、乞田川 の支川は矩形水路や暗渠に施工され雨水下水道として機 能している。本川は両岸がコンクリートブロック護岸で 整備され、河床は床止め工や落差工が施工され、河道の 安定が計られている。

\section{（2）水文観測}

雨量と気温のデータは、図ー10印に示す多摩市役所 において観測しているデータであり、1時間雨量と日平 均気温の值を用いた。水位観測は、図ー1 橋地点に設置した10分間隔で自記記録される圧力式水位 計で行っている。ただし、水位計の不調により幾つかの データが久測していたので、その期間の水位デー夕は同 地点で東京都建設局が水位計測を行っているので、その データを用いた。

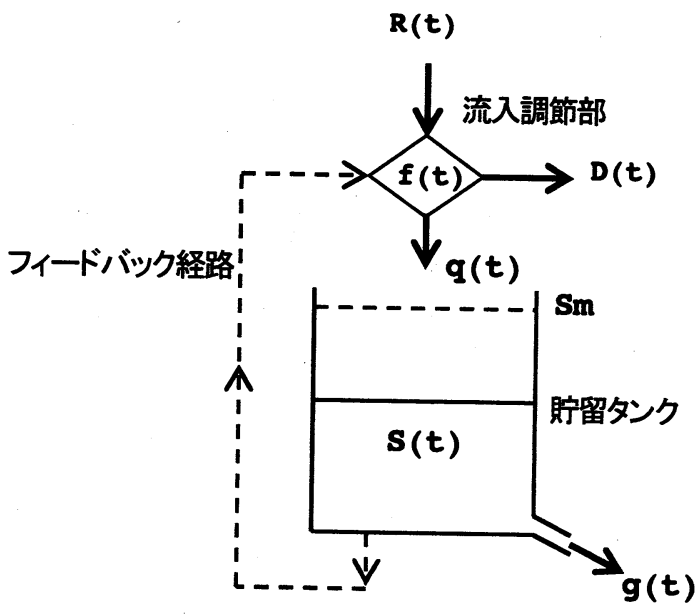

図-2 Diskin-Nazimovモデルの概要図

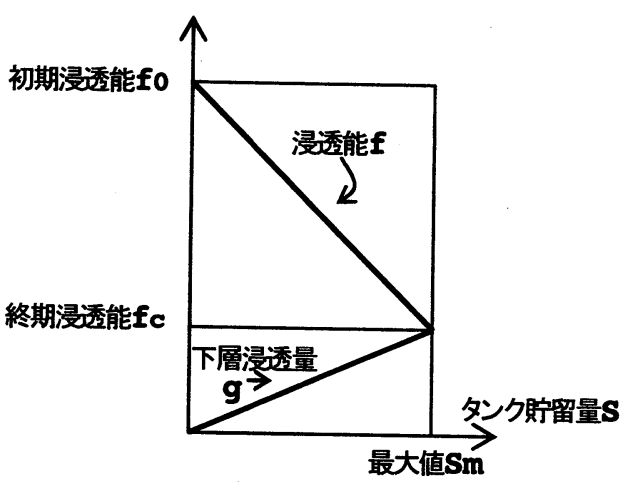

図一3 浸透能および地下水婳養量と 表層水分保留量の関係図

\section{3. 降雨強度の変化を考慮した浸透能の計算方法}

(1) Diskin-Nazimovモデルの構造

降雨強度の変化を考慮した浸透能変化の計算は、 Diskin-Nazimovモデルによって行う。Diskin-Nazimovモ デルの構造は、図ー2に示すように、貯留タンク、 フィードバック経路および流入調節部から構成される。 貯留タンクの貯留量は表層土塨の水分保留状態を表す。 貯留タンクへの流入量は、流入調節部で降雨強度 $(R)$ と 浸透能(f)の関係から表層土塞への実浸透量 (q) として 算定される。貯留夕ンクに流入しない降雨成分は直接流 出量 (D) となる。以下に実浸透量 $(q)$ と直接流出量 (D) を算定する条件式を示す。

$$
\text { if } \begin{aligned}
R(t) & \leqq f(t) \text { then } \\
q(t) & =R(t) \text { and } D(t)=0
\end{aligned}
$$

if $R(t)>f(t)$ then

$$
q(t)=f(t) \text { and } D(t)=R(t)-f(t)
$$

実際の降雨下での浸透現象は、表層土壌の水分量が増 加すれば浸透能は減少し、同時に下層への浸透量が増加 すると考えられる。この関係は図一3に示すように、夕 ンクの貯留量(S)の関数として、初期浸透能( $\mathrm{fo}$ )、終期 浸透能 $\left(f_{c}\right)$ 、表層水分保留量の最大值 $(\mathrm{Sm})$ の 3 つのパ 
ラメータを用いて、浸透能(f)および下層への浸透量 (g)を線形式として次のように表すことができる。

$$
\begin{aligned}
& f(t)=f_{0}-\frac{\left(f_{0}-f_{c}\right)}{S m} S(t) \\
& g(t)=\frac{f_{c}}{S m} S(t)
\end{aligned}
$$

また、貯留タンクの収支を表す連続式は次式となる。

$$
\frac{d S(t)}{d t}=q(t)-g(t) \quad(0 \leqq S(t)<S m)
$$

\section{（2）降雨強度の変化を考慮した浸透能の解析方法}

浸透能および下層浸透量は、式(5)からタンク貯留量 $S(t)$ を求め、それを式(3)、式(4)に代入して算定する。 解析は逐次計算により行う。従って、式(3)、式(4)、式 (5)は時間刻みの添え字を用いて次のように表す。

$$
\begin{aligned}
& \frac{f_{b}+f_{e}}{2}=f_{0}-\frac{f_{0}-f_{c}}{S_{m}} \cdot \frac{S_{b}+S_{e}}{2} \\
& \frac{g_{b}+g_{e}}{2}=\frac{f_{c}}{S_{m}} \cdot \frac{S_{e}+S_{b}}{2} \\
& \frac{S_{e}-S_{b}}{\Delta t}=\frac{q_{b}+q_{e}}{2}-\frac{g_{b}+g_{e}}{2}
\end{aligned}
$$

ここに、 $\Delta \mathrm{t}:$ 時間ステップ、 $\mathrm{b}$ : 時間刻み始めの添え字、 $\mathrm{e}:$ 時間刻み終わりの添え字。

つまり、式(8)の貯留量の終值Seを求め、浸透能fおよび 下層浸透量 $\mathrm{g}$ を求め、再び䝪留量の終值Seを求める繰り 返し計算を行う方法である。浸透能計算は、降雨強度と 浸透能の関係を次の 3 つ場合に分けて行う。

(1) 浸透能が降雨強度より小さい場合

(2) 浸透能が降雨強度より大きい場合

(3) 浸透能が降雨強度より大きい值から小さい值に 変化する場合

それぞれの場合について、浸透能計算の基礎式となる夕 ンク貯留量Se式の誘導について以下に記す。

a）浸透能が降雨強度より小さい場合の計算式

この場合の浸透能と降雨強度の関係は図ー4(a)で表さ れ、その条件式は式(9)となる。この条件をもとに式(8) から式(10)が得られる。

$$
\begin{aligned}
& \text { if } R \geqq f_{b} \text { and } R>f_{e} \text { then } \\
& \qquad q_{b}=f_{b} \text { and } q_{e}=f_{e} \\
& S_{e}-S_{b}=\frac{f_{b}+f_{e}}{2} \cdot \Delta t-\frac{g b+g e}{2} \cdot \Delta t
\end{aligned}
$$

式(6)、式(7)、式(10)から次の貯留量Se式が得られる。

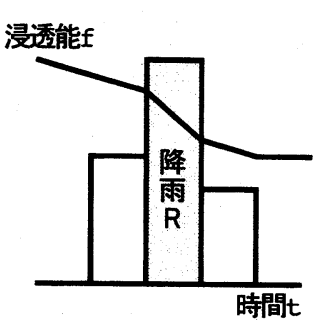

(a)浸透能が降雨強度より 小さい場合

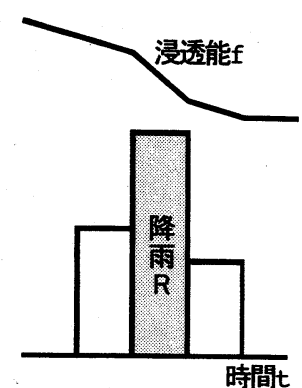

(b)漫透能が降雨強度より 大きい場合

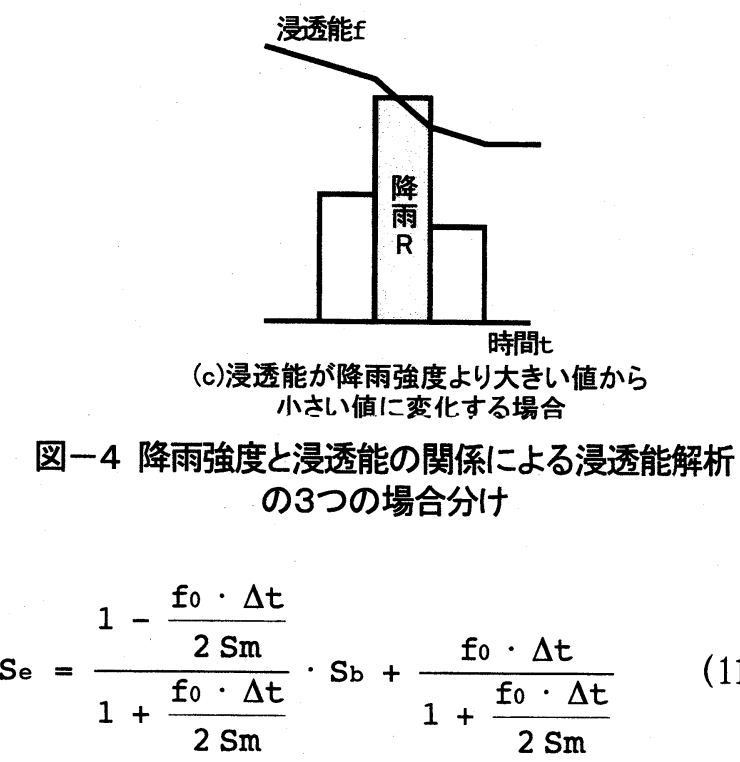

逐次計算により、1つ前の時間ステップで得られた夕 ンク貯留量 $\mathrm{Se}$ の值を新たな時間ステップで入力值 $\mathrm{S} b$ とし て貯留量Se式に代入し、新規のSe值を得る。このSe值よ り浸透能毛と下層浸透量gが計算できる。

b）浸透能が降雨強度より大きい場合の計算式

この場合の浸透能と降雨強度の関係は図一4(b)で表さ れ、その条件式は式(12)である。これより式(8)から式 (13)が得られ、タンク貯留量Seの式(14)が得られる。

$$
\begin{aligned}
& \text { if } R<f_{b} \text { and } R \leqq f_{e} \text { then } \frac{q_{b}+q_{e}}{2}=R \\
& \text { Se }-S_{b}=R \cdot \Delta t-\frac{f_{c}}{S m} \cdot \frac{S_{b}+S_{e}}{2} \cdot \Delta t \\
& S_{e}=\frac{1-\frac{f_{c} \cdot \Delta t}{2 S m}}{1+\frac{f_{c} \cdot \Delta t}{2 S m}} \cdot S b+\frac{\Delta t}{1+\frac{f_{c} \cdot \Delta t}{2 S m}} \cdot R
\end{aligned}
$$

c）浸透能が降雨強度より大きい值から小さい值に変化 する場合の計算式

この場合の浸透能と降雨強度の関係は図ー4(c)で表さ れる。時間ステップの始点から浸透能が降雨強度に等し くなるまでの時間を $\Delta t_{1} 、 \Delta t_{1}$ から時間ステップの終点 までの時間を $\Delta t_{2}$ とする。まず、 $\Delta t_{1}$ 時点の表層水分保 留量 $\mathrm{s}_{\mathrm{r}}$ を求める。そして、 $\Delta \mathrm{t}_{1}$ 時点での条件 $\mathrm{f}(\mathrm{t})=\mathrm{R}$ を 式(3)に代入して式(15)が得られ、これを変形して貯留 
量 $\mathrm{S}_{r}$ の式(16)が得られる。

$$
\begin{aligned}
& R=f_{0}-\left(f_{0}-f_{c}\right) \frac{S_{r}}{S m} \\
& S_{r}=\frac{f_{0}-R}{f_{0}-f_{c}} \cdot S m
\end{aligned}
$$

$\Delta t_{1}$ 区間の貯留量変化は、浸透能が降雨強度よりも大き い(2)の場合と同じであるので、式(13)のSeを $\mathrm{S}$ とし、 $\Delta t を \Delta t_{1}$ として書き換え、 $\Delta t_{1}$ を求める。

$$
\begin{gathered}
S_{r}-S_{b}=R \cdot \Delta t_{1}-\frac{f_{c}}{S m} \cdot \frac{S_{b}+S_{r}}{2} \cdot \Delta t_{1} \\
\Delta t_{1}=\frac{S_{r}-S_{b}}{R-\frac{f_{c} \cdot\left(S_{b}+S_{r}\right)}{2 S_{m}}}
\end{gathered}
$$

$\Delta t_{2}$ 区間の貯留量変化は、浸透能が降雨強度よりも小さ い(1)の場合と同じであるので、式(11)のSbを $\mathrm{S}$ とし、 $\Delta t を \Delta t_{2}$ として、終点の貯留量 $S$ e式(19)が得られる。

$$
\begin{array}{r}
S_{e}=\frac{1-\frac{f_{0} \cdot \Delta t_{2}}{2 \mathrm{Sm}}}{1+\frac{f_{0} \cdot \Delta t_{2}}{2 \mathrm{Sm}}} \cdot S_{r}+\frac{f_{0} \cdot \Delta t_{2}}{1+\frac{f_{0} \cdot \Delta t_{2}}{2 \mathrm{Sm}}} \\
\left(\Delta \mathrm{t}_{2}=\Delta t-\Delta \mathrm{t}_{1}\right)
\end{array}
$$

\section{4. 乞田川流域における水循環解析}

\section{（1）都市流域の 1 時間単位の水循環モデル}

水循環モデルの構造は、Diskin-Nazimovの雨水浸透モ デル、地下水涵養モデル、地下水流出モデルから構成さ れる。これは安藤・虫明・高橋 ${ }^{6}$ が多摩ニュータウン地 区の都市小流域の永山試験流域において開発し、その後、 安藤・藤村・荒井 ${ }^{8}$ が国分寺試験流域に適用した 1 時間 単位の水循環モデルにDiskin-Nazimovモデルを組み込ん だモデルであり、図一5にそのフロー図を示す。

まず、Diskin-Nazimovモデルにより 1 時間雨量から土 地利用別に表層浸透能(f)を算定し、そして不飽和帯へ の浸透量 $(g)$ と直接流出量 (D) を算定する。次に、不飽 和帯への補給量として浸透域の表層からの浸透量 $(\mathrm{g})$ と 水道漏水 (WS) を考え、消失量として蒸発散 $(E)$ と地下 水涵養量 (G) を考える。実際の蒸発散は表層から行われ ているが、蒸発散と土堙の浸透能との関係は解明されて おらず、Diskin-Nazimovモデルに組み込むことは困難な ので、従来のモデルの通り不飽和帯の水分量から蒸発散 量を差し引く。蒸発散量の算定は、Hamon式により計算 した日蒸発散量に永山試験流域で得られている24時間の 蒸発散量の割合をかけて 1 時間当りの蒸発散量とした。 不飽和帯からの地下水涵養は、不飽和帯の水分保留量 (Ms') が最小容水量 $(\mathrm{Mn})$ より小さいときは行われず、 大きいときにはその超過保留量( Ms'-Mn) に比例定数 $\beta$ を乗じた量とし、超過保留量がある一定値hを超えたと きには地下水涵養能 $(g g)$ で涵養されるとする。 hは 5 .0、

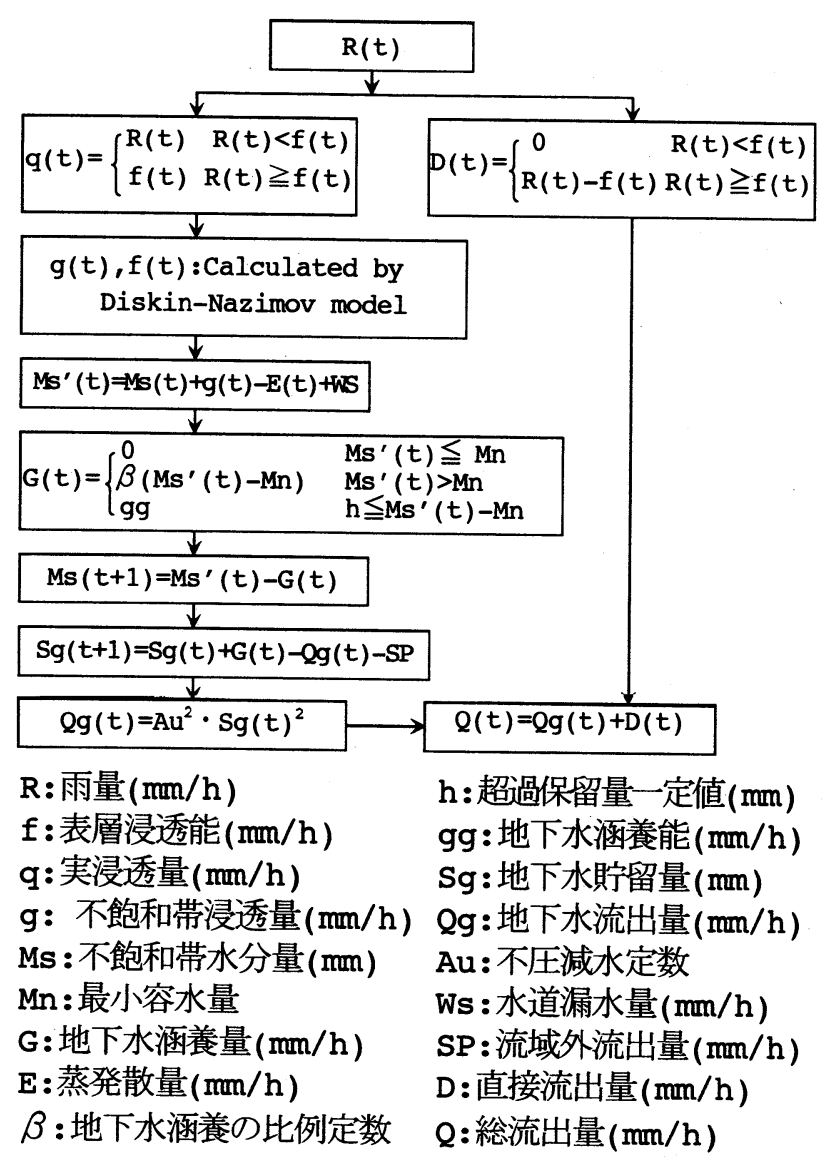

図一5 水循環モデルのフロ一図

ggは0.5 設定した。地下水流出量 $(\mathrm{Qg})$ は不圧減水定数 $\mathrm{Au}$ の 2 乗を比例定数とし、地下水貯留量 $(\mathrm{Sg})$ の 2 乗に 比例して流出する。地下水貯留量 $(\mathrm{Sg})$ には地下水涵養 量 (G)を加え、逆に流域外流出量や深層地下への漏水な どの消失量 $(\mathrm{Sp})$ を差し引く。結局、地下水流出量 $(\mathrm{Qg})$ に直接流出量 $(D)$ を加えたものが河川流出量 $(Q)$ となる。

\section{（2）生活雑排水と水道漏水量}

対象流域は都市流域であることから、生活雑排水量と 水道漏水量を考慮する。乞田川流域は分流式下水道がほ ぼ100\%整備されているが、無降雨期間において観測地 点の水位に日周変動が見られる。このことは河川水に生 活雑排水が混入していると考えられる。従って、無降雨 期間において 1 日の最低流量を地下水流出と考え、それ を上回る量を生活雑排水として考え、6つ無降雨期間に ついて計算した結果、 $0.0356 \mathrm{~mm} / \mathrm{day}$ と算定された。一方、 水道漏水量については、多摩ニュータウン地域の漏水量 は $5.8 \% て ゙ 1,829 \mathrm{~m}^{3} /$ dayと見積もられている。これを流出 高に換算し、0.14mm/dayを不飽和帯に加えた。

\section{(3) 解析結果と考察}

1996年3月28日から2001年2月28日までの対象期間のう ち、途中大幅な水位デー夕の欠測があったため、対象期

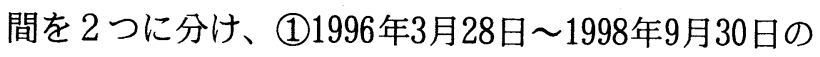
917日間と (2)1999年2月19日〜2001年2月28日の740日間 とした。 


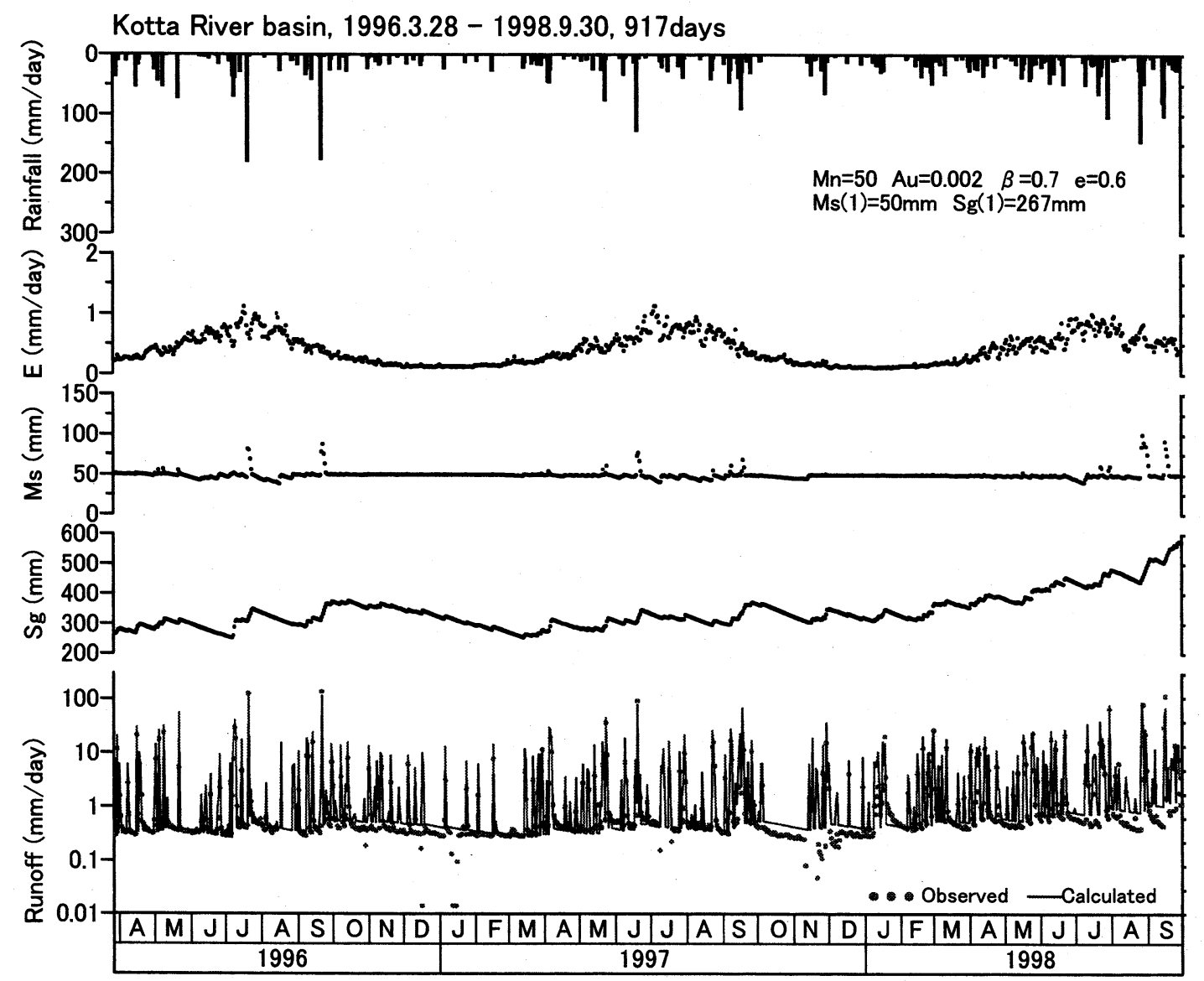

図－ 6 対象期間(1)の解析結果(1996年3月28日～1998年9月17日、917日間)

Kotta River basin, 1999.2.20 - 2001.2.28, 740days

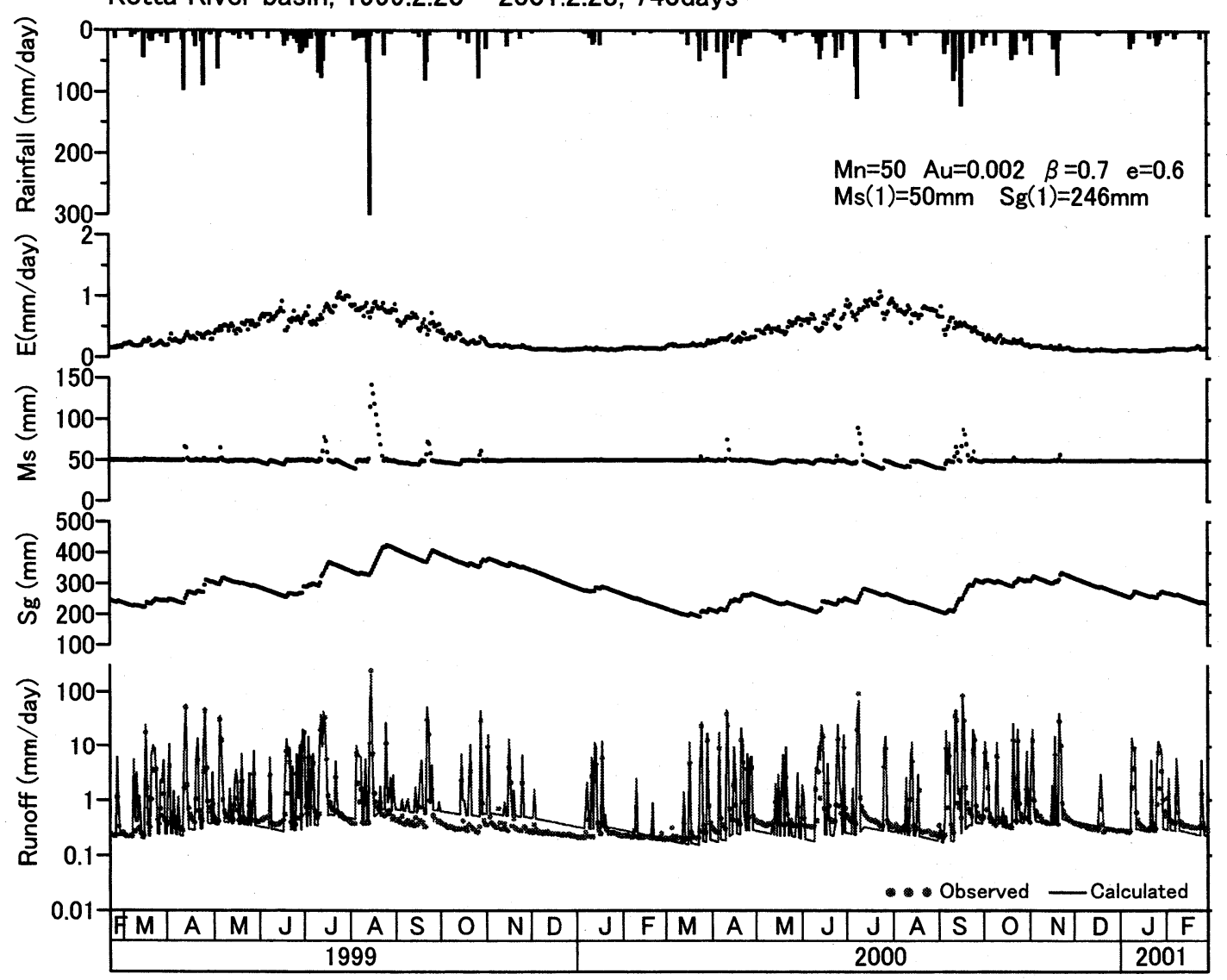

図一 7 対象期間(2)の解析結果(1999年2月20日〜2001年2月28日、740日間) 
表一2 解析に用いたパラメータと初期値

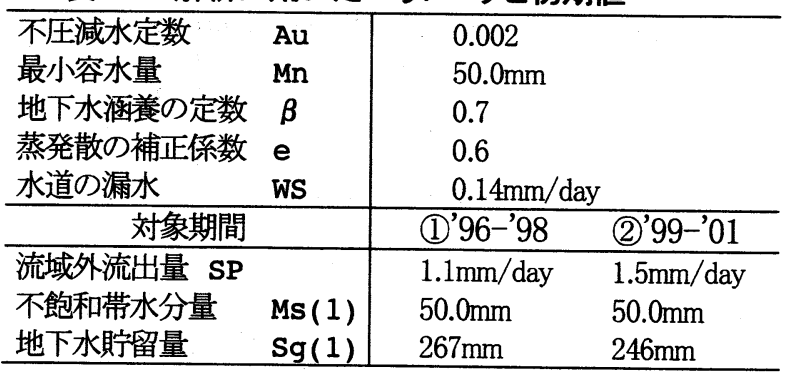

表-3 初期浸透能亡終期漫透能 (単位: $\mathrm{mm} / \mathrm{h}$ )

\begin{tabular}{|c|c|c|c|c|c|c|}
\hline & 道路 & 屋根 & 芝地 & グランド & 造成地 & 林地 \\
\hline 終期浸透能 fc & 0.01 & 0.01 & 22.2 & 7.1 & 5.3 & 100.0 \\
\hline 水分保留量最大Sm & 2.0 & 2.0 & 19.5 & 8.4 & 10.0 & 100.0 \\
\hline 初期浸透能 fo & 1.0 & 1.0 & 30.0 & 10.0 & 10.0 & 150.0 \\
\hline
\end{tabular}

$2 つ$ つ対象期間の解析ハイドログラフを図ー 6と図 - 7に示す。いずれも計算ハイドログラフは実測ハイ ドログラフによく適合している。両図には蒸発散量の変 化、不飽和帯水分量の変化、地下水貯留量の変化を同時 に示す。地下水貯留量の変化と低水部のハイドログラフ の傾向が近似しており、地下水流出は地下水貯留量に顕 著に影響されていることが分かる。解析に用いたパラ メー夕と初期值について表一2に示す。不圧減水定数Au は、実測ハイドログラフの低減部に計算ハイドログラフ が適合するように試算により求め0.002とした。流域外 流出量の值は $2 つ の$ 期間に対しそれぞれ適合したハイド ログラフを得るため異なる数值を設定し、 $1.1 \mathrm{~mm} / \mathrm{day}$ と $1.5 \mathrm{~mm} /$ day とした。実際、乞田川流域の流域外流出のプ ロセスは明らかでないが、貯留された地下水が透水層で ある御殿峠碟層や稲城砂層を通じ流域外に流出している か、あるいは深層地下へ浸出していることなどが考えら れる。浸透能に関するパラメータを表一3に示す。終期 浸透能fc と表層水分保留量の最大值Smの值は、土地利 用別に散水浸透実験を行い得た値とその解析值を用いた 4)、9)。また、両対象期間の解析した水収支量を表一4に 示す。この表から乞田川流域の特徵として、直接流出の うち浸透域からの流出はそれほど多くはなく、また、流 域外流出量が比較的多いことが分かる。

\section{5. まとめ}

本研究では、降雨強度の変化を考慮して浸透能計算が 行える比較的簡単な構造のDiskin-Nazimovモデルについ て説明した。そして、多摩ニュータウン地域の都市河川 流域である乞田川流域を対象に、安藤ら ${ }^{6)}$ の 1 時間単位 の水循環モデルに有効降雨モデルとしてDiskin-Nazimov モデルを組み込み、降雨強度の変化に対する浸透能変化 を考慮した水循環解析を約 5 年間の資料を用いて行い、 その適合性について検討した。その結果、地下水流出の ハイドログラフの再現性は良好であったことから、この
表－4 対象期間の水収支量 （単位: $\mathrm{mm}$ )

\begin{tabular}{|l|c|c|}
\hline 対象期間 & (1'96-'98, 917d & (2'99-'01, 740d \\
\hline 総雨量 & 4848 & 3670 \\
\hline 水道漏水量 & 128 & 104 \\
\hline 直接流出量 & 2843 & 2138 \\
(浸透域流出量) & $(165)$ & $(113)$ \\
\hline 地下水流出量 & 444 & 248 \\
\hline 流域外流出量 & 1008 & 1110 \\
\hline 蒸発散量 & 376 & 289 \\
\hline 地下水貯留量差 & 307 & -11 \\
\hline
\end{tabular}

水循環モデルの実流域に対する適用可能性が示されたと 言える。都市河川流域の低水流出について検討すること は、親水計画等における環境維持流量を把握する上で重 要であり、本研究はその基礎研究であると考えている。

今後の検討課題は、地下水位や蒸発散量などの実測值 をそろえてモデル精度を多面的に検討すること、さらに、 低水流出のみならず洪水流出の再現性についても同時に 検討することである。

謝辞: 本研究を進めるに当り、雨量データと気温デー夕 を提供して頂いた多摩市役所環境部の関係各位、水位 データを提供して頂いた東京都建設局土木技術研究所河 川部の関係各位、また、プログラミングに協力して頂い た当時学生の奈良崎忍君に記して感謝の意を表します。

\section{参考文献}

1) Smith, R. E.: The infiltration envelope: Results from a theoretical infiltrometer, J. Hydrology, Vol.17, pp.1-21, 1972.

2) Mein, R. G. and Larson, C. L.: Modelling infiltration during a steady rain, Water Resources Res., Vol.9, No.2, pp384-394, 1973.

3) Diskin, M. H. and Nazimov, N.: Linear reservoir with feedback regulated inlet as a model for the infiltration process, J. Hydrology, Vol.172, pp.313-330, 1995.

4) 藤村和正, 安藤義久, 山田富美夫, 山中理 : 定常降雨による 湛水発生時間及び浸透能に関する研究, 水工学論文集, 第 44 巻, pp.193-198, 2000.

5) Fujimura, K. and Ando, Y.: Analysis infiltration capacity of upper soil layer during unsteady rainfall, Proceedings of The Urban Drainage Modeling Symposium, CD-ROM, Florida, USA, 2001. (In Press)

6) 安滕義久, 虫明功臣, 高橋裕 : 丘陵地の水循環機構とそれに 対する都市化の影響，第25回水理講演会論文集，pp.197-208， 1981.

7) 安藤義久 : 丘陵地の水循環機構と都市化によるその変化に関 する研究, 東京大学学位論文, p.235, 1981.

8) 安藤義久, 藤村和正, 荒井竜司 : 武藏野台地の湧泉の水循環 解析と流域管理, 水工学論文集, 第40巻, pp.225-230, 1996. 9) 安藤義久: 都市域の浸透能と地形・地質・土地利用との対応関 係, 水工学論文集, 第35巻, pp.123-128, 1991.

（2001.10.1受付） 